\title{
Rancang Bangun Alat Tanam Benih Kangkung Darat (Ipomoea Raptana Poir)
}

\section{Design of Kale Spinach Seed Planting Tools (Ipomea raptana Poir)}

\author{
Fajarsukoco, Nasichin, Duta Satria M.Y., Yose Sebastian, dan Meinilwita Yulia \\ Jurusan Teknologi Pertanian,Politeknik Negeri lampung \\ Jl. Soekarno-Hatta No. 10 Rajabasa-Bandar Lampung, 35144
}

\begin{abstract}
Kale spinach is a type of vegetable that is widely consumed by people in Indonesia. It's contains protein, carbohydrates, calcium, iron, sodium, phosphorus, fiber, vitamins $A$ and $C$. The kale spinach is a low-calorie vegetable. The purpose of this research is to design kale spinach seed planting tool with a semi-mechanical system which power comes from human power, this tool is operated by pulling a lever on the tool so that the tool can work. After the manufacture of kale seed planting is complete, the authors test the performance of the tool capacity, and from the results of the performance test of this tool it can be concluded that it can work well. The results of the performance test of the capacity of this tool to plant water spinach seeds with an area of 0.0005 ha takes 0.007 hours with an average speed of $0.2 \mathrm{~m} / \mathrm{s}$, the average seeds that fall per hole are 3 seeds, $98.6 \%$ efficiency, The theoretical capacity is 0.072 ha/hour, the effective capacity is 0.071 ha/hour, the percentage of growth is $95 \%$, the average distance between plants is $10 \mathrm{~cm}$, and the average distance between rows of plants is $10 \mathrm{~cm}$.
\end{abstract}

Keywords: kale spinach, planting, and spacing

Naskah ini diterima pada tanggal 1 Juli 2020, direvisi pada tanggal 15 Juli 2020 dan disetujui untuk diterbitkan pada tanggal 15 Agustus 2020

\section{PENDAHULUAN}

Kangkung darat merupakan tumbuhan jenis sayur-sayuran yang banyak dikonsumsi oleh masyarakat di Indonesia. Kangkung darat mengandung protein, karbohidrat, kalsium, zat besi, natrium, fosfor, serat, vitamin A dan C. Meskipun kaya akan berbagai nutrisi, kangkung darat merupakan salah satu jenis sayuran yang rendah kalori (Sulaiman, 2017).

Saat ini kangkung darat banyak dikonsumsi dan dibudidayakan oleh masyarakat Karena, harga kangkung darat yang relatif cukup murah dibandingkan dengan sayuran lainnya. Budidaya kangkung darat sangat mudah dan siklus panen yang cepat. Kangkung darat dapat dibudidayakan baik didataran rendah maupun dataran tinggi. Tanaman kangkung darat dapat berkembang dengan baik apabila kebutuhan air dan sinar matahari tercukupi.

Terdapat empat cara penanaman benih kangkung, dari ke empat antara lain: Sistem sebar, barisan, hundular dan bujur sangkar (persegi panjang). Pada keempat sistem tersebut memiliki kelebihan dan kekurangannya masing-masing. Sistem penanaman benih kangkung

116 Volume 12, Nomor 2| Agustus 2020: 65-126 
yang paling banyak digunakan oleh petani adalah sistem bujur sangkar. Sistem persegi panjang (bujur sangkar) dipilih petani karena, meminimalisir persaingan dalam mencari nutrisi untuk bertumbuh kembang dan memudahkan dalam melakukan penyiangan.

Penanaman pada budidaya kangkung darat biasanya dilakukan dengan cara manual yaitu menggunakan jari atau tugal yang kedalamannya kurang lebih $2 \mathrm{~cm}$ dengan setiap lubang diberi isi 2 benih kangkung darat. Metode penanaman secara manual akan membutuhkan waktu yang lama untuk menyelesaikan proses penanaman.

Upaya meningkatkan produktifitas penanaman benih kangkung darat dibutuhkan alat yang efektif dan efisien. Sehingga dapat mempermudah petani dalam proses penanaman benih kangkung. Adanya alat tersebut membantu petani untuk menekan biaya produksi dan dapat meminimalisir modal.

Adanya masalah tersebut diatas maka timbulah inovasi untuk membuat alat penanam benih kangkung yang berjudul “'Rancang Bangun Alat Penanam Benih kangkung Darat" yang berfungsi untuk mempercepat dalam proses penanaman benih kangkung dengan sistem persegi panjang (bujur sangkar). Sehingga dengan adanya alat penanam benih kangkung ini petani diharapkan dapat terbantu dalam pekerjaannya.

Tujuan dari rancang bangun alat penanam benih kangkung darat yaitu, (1) merancang dan membuat alat penanam benih kangkung darat, (2) menguji kinerja alat penanam benih kangkung darat.

\section{METODOLOGI}

Pembuatan alat ini dilaksanakan pada tanggal 30 September sampai 29 November 2019 di Bengkel Produksi, Politeknik Negeri Lampung.

Adapun alat yang digunakan antara lain: Las Listrik, Mesin Bubut, Bor Listrik, Gerinda, Toll Set, Mistar Siku, Jangka Sorong, Tang, Palu, Sarung Tangan, Kaca Mata las, Roll Meter. Sedangkan bahan yang digunakan antara lain: besi siku $3 \times 3 \mathrm{~mm}$, besi plat ketebalan 1,2 $\mathrm{mm}$, besi pipa $\varnothing 3 / 4$ ", teflon panjang $100 \mathrm{~cm}$, baut dan mur, roda kereta anak2 $\varnothing 32 \mathrm{~cm}$, bearing pilow UCF 204, dempul, mata bor $10 \mathrm{~mm}$, besi as $3 / 4$ ", elektroda las, mata gerinda, amplas, dempul, dan benih Kangkung darat.

\section{Rancangan Alat}

Rancangbangun alat penanam benih kangkung darat yang dibuat dirancang untuk dapat menanam dengan jarak $10 \mathrm{~cm} \times 10 \mathrm{~cm}$ dan dengan jumlah benih perlubang 2 biji. Alat penanam benih kangkung darat ini terdiri dari komponen-komponen : kerangka, hopper, seed plate, roda, pembuka alur, saluran benih, papan penutup alur, dan bearing (Gambar 1). 


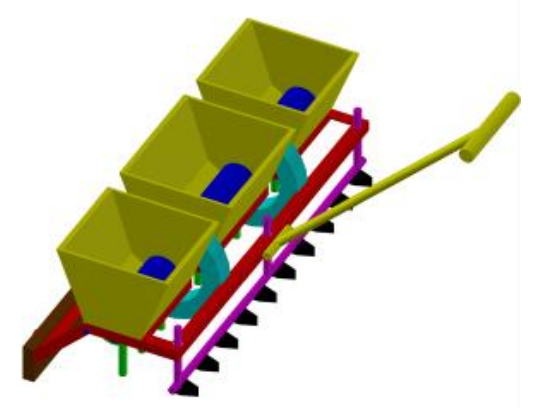

Gambar 1. Gambar rancangbangun alat penanam benih kangkung darat

Adapun rancangan masing-masing komponen adalah sebagai berikut:

a. Kerangka alat

Kerangka ini berfungsi sebagai tempat dipasangkannya komponen-komponen alat lainnya seperti hopper, pembuka alur, roda, Seed Metering Device, saluran benih, papan penutup alur dan bearing. Kerangka ini terbuat dari besi siku $30 \mathrm{~mm}$ x $30 \mathrm{~mm}$ dengan ketebalan $3 \mathrm{~mm}$ yang disatukan dengan cara dilas (Gambar 2).

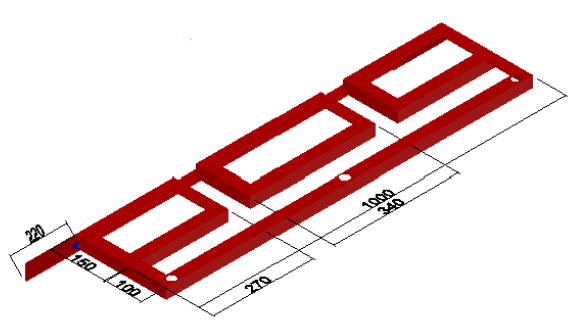

Gambar 2. Kerangka alat

b. Hopper

Hopper berfungsi sebagai kotak penampung benih sebelum disalurkan/ditanam ke tanah. Hopper ini terbuat dari besi plat dengan ketebalan 1,2 $\mathrm{mm}$ dan menempel pada kerangka dengan cara dilas (Gambar 3).

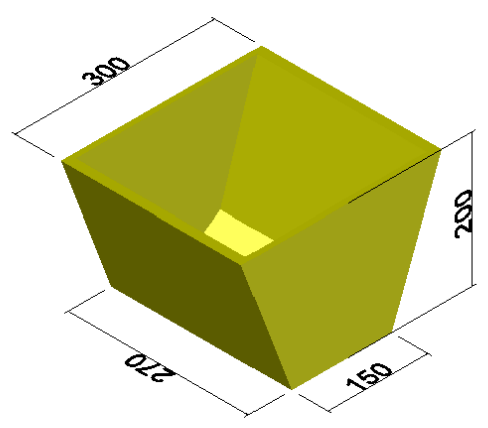

Gambar 3. Hopper

118 Volume 12, Nomor 2| Agustus 2020: 65-126 
c. Seed Metering Device

Seed Metering Device merupakan bagian komponen alat tanam benih yang berfungsi untuk mengatur pengeluaran benih (jarak tanam dan jumlah benih per lubang). Seed Metering Device tersebut terbuat dari pipa pvc atau teflon dengan jari-jari 22,5 mm (Gambar 4).

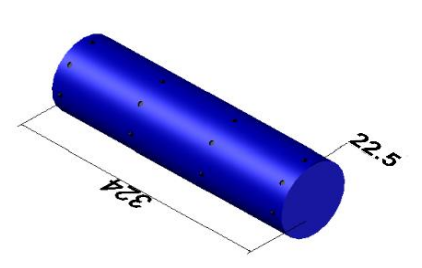

Gambar 4. Seed Metering Device

d. Roda

Roda digunakan untuk membantu alat tersebut untuk bergerak maju atau mundur dengan gerakan berputar yang juga sekaligus untuk memutar Seed Metering Device. Roda yang digunakan berjumlah dua buah roda dengan jari-jari $150 \mathrm{~mm}$. Roda yang digunakan terbuat dari plat besi yang kuat (Gambar 5).

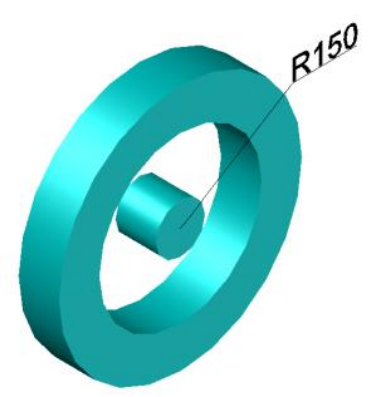

Gambar 5. Roda

e. Pembuka alur

Pembuka alur merupakan salah satu komponen alat tanam benih yang berfungsi untuk membuka alur tanam yang selanjutnya benih akan dijatuhkan di belakangnya. Pembuka alur tersebut terbuat dari plat dengan tebal $3 \mathrm{~mm}$ bentuk prisma segitiga.

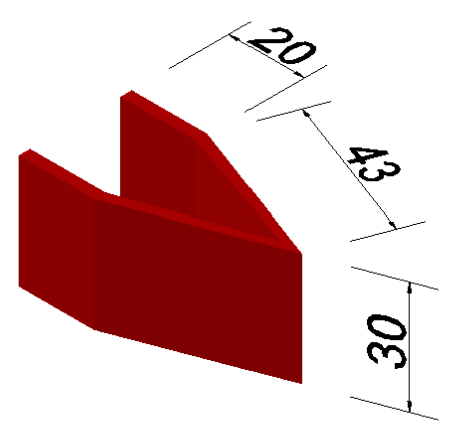

Gambar 6. Pembuka alur 
e. Saluran benih

Saluran pengeluaran benih berfungsi untuk dari hopper akan diteruskan ke dalam tanah untuk proses penanaman. Saluran ini berbentuk kerucut yang ujungnya diberi pipa untuk diteruskan ke saluran benih sehingga benih tersebut dapat tertanam. Bahan saluran benih terbuat dari pipa/selang plastik dengan diameter 1/2 " (Gambar 7).

f. Papan penutup alur

Papan penutup alur berfungsi sebagai penutup alur benih agar benih tertutup oleh tanah setelah jatuh ke permukaan tanah. Komponen ini terbuat dari papan dengan ketebalan 30 mm, Panjang 1000 mm dan tinggi 100 mm (Gambar 8).

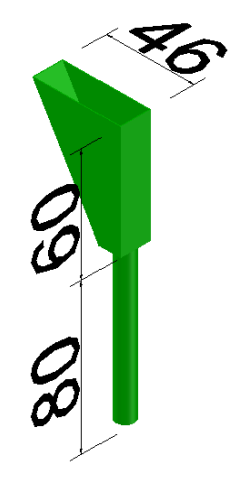

Gambar 7. Saluran benih

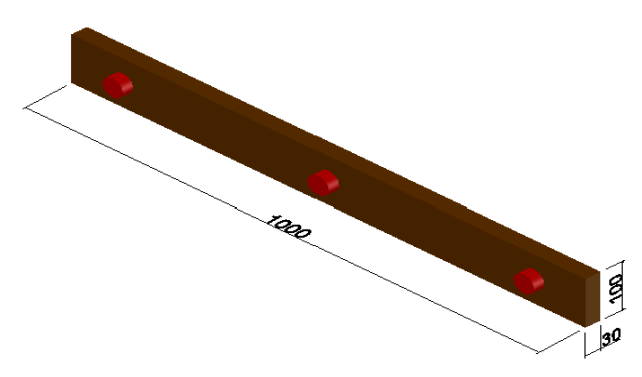

Gambar 8. Papan penutup alur

\section{g. Bearing}

Bearing berfungsi sebagai dudukan roda dan Seed Metering Device yang bergerak untuk mengeluarkan benih. Bearing yang digunakan berjumlah dua buah bertipe pilow blok UCF 204 berdiameter 3/4". Bantalan ini diperoleh dari pasar alat-alat pertanian yang dipasangkan pada kerangka yang dihubungkan dengan mur dan baut dengan ukuran $12 \mathrm{~mm}$ (Gambar 9).

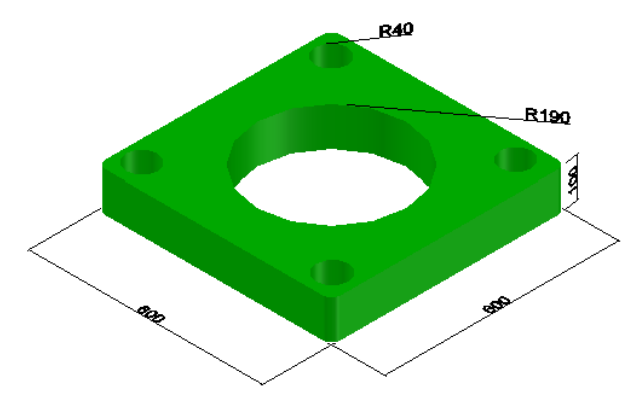

Gambar 9. Bearing

\section{Prosedur Perakitan}

Berikut merupakan prosedur perakitan alat penanam benih kangkung darat:

a. Menyiapkan alat dan bahan; 
b. Memasang bearing pada kerangka alat dengan dimur dan dibaut lalu dikencangkan;

c. Memasang as roda kemudian dihubungkan dengan seed plate menjadi satu poros;

d. Memasang roda pada poros as roda;

e. Memasang hopper pada kerangka kemudian dikencangakan dengan mur dan baut;

f. Memasang bagian pembuka alur pada kerangka kemudian dimur serta dibaut lalu dikencangkan;

g. Memasang penutup alur pada kerangka kayu pada bagian belakang;

h. Memasang tuas kendali pada kerangka untuk mengoperasikan alat tersebut.

\section{Uji Kinerja}

Pengujian dilakukan untuk mengetahui sejauh mana kemampuan alat untuk menebarkan benih kangkung darat. Pengujian ini dilakukan untuk mengetahui tentang spesifikasi alat penanam benih kangkung darat. Berikut ini adalah beberapa parameter pengujian alat penanam benih kangkung darat:

a. Kapasitas kerja lapang teoritis dan kapasitas lapang efektif alat penanam benih kangkung dalam satuan ha/jam;

b. Efisiensi lapang pada saat proses penanaman (\%);

c. Jumlah benih per lubang. Jumlah benih per lubang yang diinginkan yaitu dua benih per lubang. Adapun pengambilan data ini dilakukan dengan pengambilan lima sample secara acak, kemudian menghitung jumlah isi benih pada masing-masing lubang. Setelah didapatkan hasil pada setiap lubang kemudian dihitung rata-rata benih tiap lubang dan dihitung persentase benih tertanam.

e. Jarak tanam dalam barisan tanaman. Jarak yang diinginkan adalah $10 \mathrm{~cm}$. Adapun pengambilan data ini dilakukan dengan pengambilan lima sample secara acak, kemudian dihitung rata-rata jarak tanam dalam barisan tanaman tersebut.

f. Jarak antar barisan tanaman. Jarak yang diinginkan adalah $10 \mathrm{~cm}$. Adapun pengambilan data ini dilakukan dengan pengambilan lima sample secara acak, kemudian dihitung rata-rata jarak antar barisan tanaman tersebut.

g. Menghitung persentase benih tumbuh dari penggunaan alat penanam benih kangkung darat tersebut.

\section{HASIL DAN PEMBAHASAN}

Rancang bangun alat penanam benih kangkung darat telah berhasil dibuat (Gambar 10). Adapun spesifikasi dimensi alat penanam benih kangkung darat yang sudah dibuat seperti disajikan pada Tabel 1 . 

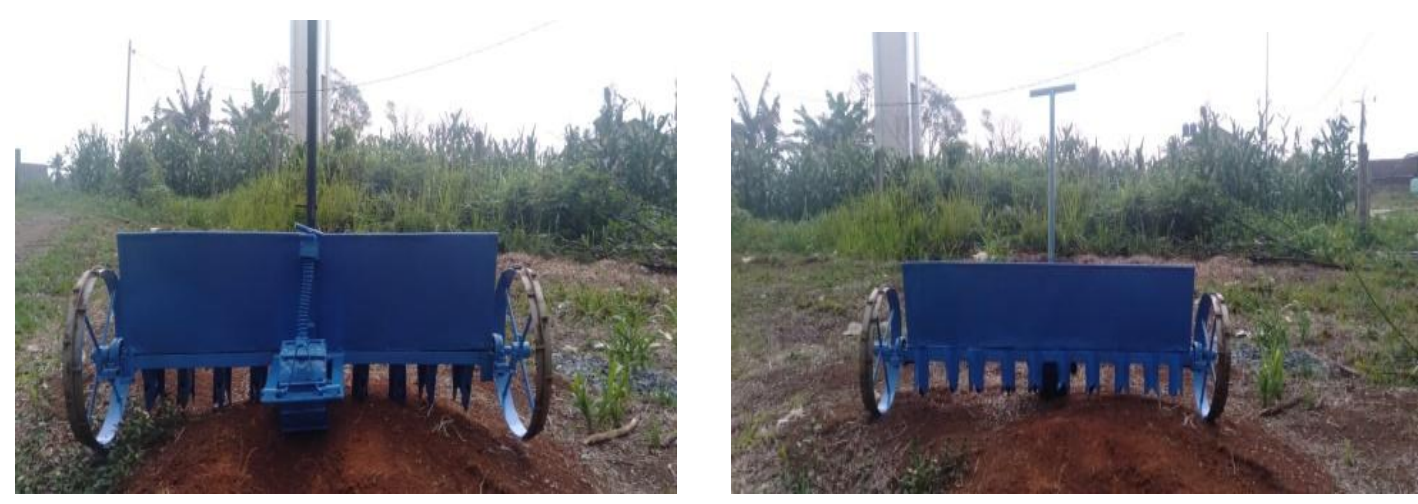

Gambar 10. Hasil rancangbangun alat penanam benih kangkung darat

Tabel 1. Spesifikasi dimensi Alat penanam benih kangkung darat

\begin{tabular}{clc}
\hline No & \multicolumn{1}{c}{ Nama } & Spesifikasi Alat \\
\hline 1 & Panjang hopper $(\mathrm{cm})$ & 100 \\
\hline 2 & Panjang alat $(\mathrm{cm})$ & 120 \\
\hline 3 & Lebar hoper atas $(\mathrm{cm})$ & 25 \\
\hline 4 & Lebar hopper bawah $(\mathrm{cm})$ & 10 \\
\hline 5 & Tinggi hopper $(\mathrm{cm})$ & 20 \\
\hline 6 & Diameter Seed Metering Device $(\mathrm{cm})$ & 4,7 \\
\hline 7 & Diameter Roda $(\mathrm{cm})$ & 32 \\
\hline 8 & Kapasitas Hopper $(\mathrm{kg})$ & 21,21 \\
\hline
\end{tabular}

Dalam proses pembutan alat tanam benih kangkung darat (Ipomoea reptana Poir) dengan semi mekanis penulis merakit antara komponen-komponen dengan hati-hati, bahan yang digunakan merupakan bahan yang cukup mudah untuk dicari dari barang-barang bekas dan ada di penjual besi potong. Tahapan yang pertama pada pembuatan alat ini adalah perencanaan yang matang akan konstruksi serta pemilihan bahan-bahan yang digunakan untuk membuat alat tanam benih kangkung darat.

Kendala yang didapatkan oleh penulis dalam membuat alat tanam benih kangkung darat ini adalah ketika membuat hopper dan seed metering device, hal tersebut disebabkan kurangnya ketelitian dan kesabaran agar hopper dan kerangka dapat presisi sehingga tidak terdapat celah yang terlalu besar antara seed metering device dengan kerangka. Membuat seed metering device pada tahap ini perlu penentuan diameter dan kedalaman lubang sangat berpengaruh untuk pengaturan jumlah benih yang akan ditanam dan untuk pengaturan jarak lubang antar tanaman. Ukuran benih yang tidak seragam akan menambah kendala dalam pembuatan diameter dan lubang pada seed metering device. 
Setelah proses pembuatan alat tanam benih kangkung darat selesai maka penulis siap untuk menguji kinerja alat tanam tersebut, dalam uji kinerja yang didapatkan maka penulis dapat membandingkan hasil dari alat tanam tugal dan alat tanam semi manual. Penulis mengharapkan hasil dari alat tersebut sesuai dengan yang diinginkan yaitu alat tersebut lebih tepat dan cepat dalam menanam benih kangkung dibandingkan dengan cara manual, jarak antar tanam $10 \mathrm{~cm}$, dan jarak dalam baris tanaman $10 \mathrm{~cm}$.

Setelah didapatkan hasil jarak antar tanaman yang sesuai dengan keinginan, langkah selanjutnya adalah pengambilan data kinerja alat penanam benih kangkung darat dan kemudian melakukan pengambilan data kinerja alat tanam benih kangkung manual sebagai pembanding hasil kinerja alat tersebut.

Hasil tanam kangkung dari kedua alat tersebut adalah pada alat tanam benih kangkung darat semi manual, memiliki waktu yang lebih cepat untuk menyelesai penanaman benih kangkung, jarak antar tanaman rata-rata $10 \mathrm{~cm}$, jarak dalam baris tanaman rata-rata $10 \mathrm{~cm}$, jumlah benih dalam lubang rata-rata 3 benih per lubang, jarak yang kurang teratur dan tidak rapih dari penggunaan alat tanam benih secara semi manual. Sementara pada alat tanam secara manual membutuhkan waktu yang lebih lama untuk menanam benih kangkung, jarak antar tanaman rata-rata 10 , jarak dalam baris tanaman10 sudah sesuai dengan yang diinginkan.

\section{Data Hasil Uji Kinerja Alat}

Penulis melakukan lima pengujian alat dengan enam jumlah guludan, lima guludan digunakan untuk menguji alat tanam benih kangkung semi manual, dan satu guludan untuk menguji alat tanam benih kangkung secara manual. Luas guludan sama, masing-masing guludan berukuran $1 \mathrm{~m}$ x $5 \mathrm{~m}$. Adapun hasil uji kinerja kedua alat seperti disajikan pada Tabel 2.

Tabel 2. Data Uji Kinerja Perbandingan Alat Penanam Benih Kangkung.

\begin{tabular}{clcc}
\hline \multirow{2}{*}{ No } & \multirow{2}{*}{ Indikator } & \multicolumn{2}{c}{ Luas Lahan 1 m x 5 m } \\
\cline { 3 - 4 } & & \multicolumn{2}{c}{ Jenis Alat Tanam } \\
\cline { 3 - 4 } 1 & Luas Lahan (ha) & 0,0005 & Semi manual \\
\hline 2 & Rata-rata waktu kerja total (jam) & 0,49 & 0,0005 \\
\hline 3 & Lebar Kerja (m) & 0,00102 & 0,071 \\
\hline 4 & Kapasitas lapang efektif (ha/jam) & 0,013 & 0,072 \\
\hline 5 & Kapasitas lapang teoritis (ha/jam) & 76,92 & 98,6 \\
\hline 6 & Efisiensi lapang (\%) & 91,1 & 92 \\
\hline 7 & Rata-rata persentase tumbuh (\%) & 0,037 & 10,2 \\
\hline 8 & Kecepatan (m/s) & 10 & 10 \\
\hline 9 & $\begin{array}{l}\text { Rata- rata jarak antar } \\
\text { tanaman (cm) }\end{array}$ & 10 & 3 \\
\hline 10 & $\begin{array}{l}\text { Rata- rata jarak dalam baris } \\
\text { tanaman (cm) }\end{array}$ & 2 & $\begin{array}{l}\text { Rata- rata jumlah } \\
\text { benih per lubang (benih) }\end{array}$ \\
\hline \multirow{2}{*}{11} & & & 10 \\
\hline
\end{tabular}


Tabel 2 menunjukkan beberapa uji kinerja alat tanam yang berbeda dengan penilaian dari setiap uji alat tanam benih kangkung, terutama pada alat tanam semi mekanisyang penulis buat dengan total pengujian sebanyak lima kali dalam guludan yang sama seluas $1 \mathrm{~m}$ x $5 \mathrm{~m}$. Dari masing- masing indikator penilaian tersebut, didapatkan perhitungan yang dijadikan sebagai nilai perbandingan dengan alat tanam benih kangkung dengan alat tanam tugal.

Perbedaan pertama pada kecepatan penanaman, alat tanam tugal $0,037 \mathrm{~m} / \mathrm{s}$, dan alat tanam semi mekanis $0,2 \mathrm{~m} / \mathrm{s}$. Perbedaan kedua pada kapasitas lapang teoritis, Alat tanam tugal 0,013 ha/jam dan alat tanam semi mekanis 0,072 ha/jam, kapasitas lapang efektif pada alat tanam tugal 0,00102 ha/jam dan alat tanam semi mekanis $0,071 \mathrm{ha} / \mathrm{jam}$. Perbedaan ketiga efisiensi lapang alat tanam tugal 76,92\% dan alat tanam semi mekanis 98,6\%. Perbedaan keempat persentase benih tumbuh dengan alat tanam tugal $91,2 \%$ dan alat tanam semi mekanis $92 \%$. Perbedaan kelima yaitu rata-rata untuk jumlah benih per lubang dengan alat tanam tugal 2 benih dan menggunakan alat tanam semi mekanis 3 benih. Untuk rata jarak antar tanaman dan jarak dalam baris tanaman sudah sesuai dengan yang diinginkan yaitu jarak antar tanaman 10 $\mathrm{cm}$ dan jarak dalam baris tanaman $10 \mathrm{~cm}$.

Oleh karena itu alat penanam benih kangkung semi mekanis memiliki kekurangan adalah jumlah benih yang jatuh tidak sama, namun alat penanam kangkung semi mekanis ini memiliki efisiensi lapang tinggi dalam menyelesaikan penanaman dibandingkan dengan alat tanam tugal. Untuk pengoperasian tidak memerlukan banyak tenaga dalam penanaman kangkung. Berdasarkan hasil yang diperoleh dari hasil uji alat penanam benih kangkung ada beberapa indikator penyebab jumlah benih yang jatuh tidak sama yaitu:

1) Kedalaman lubang seed plate yang tidak sama akan menambah jumlah benih yang masuk kedalam lubang seed plate;

2) Ukuran diameter benih kangkung yang tidak sama menyebabkan jumlah benih yang masuk pada lubang seed plate tidak sama; dan

3) Terdapat bongkahan kecil tanah pada guludan atau jalur lintasan roda sehingga saat alat tersebut mengenai bongkahan, benih yang jatuh akan terpantul dan menyebabkan benih tersebut jatuh tidak pada tempatnya. Akibat dari pantulan tersebut benih akan mengalami pergeseran dari jarak yang telah ditentukan.

Bongkahan tanah ini disebabkan oleh pengolahan tanah yang kurang baik dan kurang halus. Untuk dapat bekerja dengan baik Alat tanam kangkung ini maka proses penyiapan lahan harus betul-betul sempurna dan bongkahan hasil olahan tanah yang betul-betul halus.

\section{KESIMPULAN DAN SARAN}

\section{Kesimpulan}

1) Alat penanam benih kangkung darat telah selesai dibuat dan dilakukan uji kinerja dengan mendapatkan hasil ; kecepatan laju 0,2 m/s, kapasitas kerja lapang teoritis 0,072 ha/jam, 
kapasitas kerja lapang efektif 0,071 ha/jam, efisiensi lapang 98,6\%, rata-rata 3 benih per lubang, rata-rata jarak dalam baris tanaman $10 \mathrm{~cm}$, rata-rata jarak antar tanam $10 \mathrm{~cm}$, persentase benih tumbuh $92 \%$;

2) Alat penanam benih kangkung darat yang sudah diuji ini memiiliki hasil yang lebih baik dibandingkan dengan alat penanam kangkung secara manual dan hasilnya sudah sesuai dengan yang diinginkan.

\section{Saran}

Untuk mendapatkan hasil sesuai dengan yang diinginkan perlu perencanaan yang matang agar kesalahan yang terjadi bisa diminimalisir. Misalnya, dalam penyiapan lahan agar betul-betul halus hasil penggaruannya, didalam pembuatan seed metering device perlu betulbetul2 presisi ukurannya, sedangkan untuk mengantisipasi jumlah benih yang keluar perlu betul-betul pemilihan ukuran benih yang seragam.

\section{DAFTAR PUSTAKA}

Anonim. 2013. Morfologi Tanaman Kangkung.http://agroekoteknologi08. wordpress. com/2013/07/12/morfologi tanaman kangkung/. [diakses pada 19 Agustus 2019].

Anonim. 2015 . As Roda Gila. https://swingwheel.wordpress.com/komponen-Swing-wheel /as-roda-gila/. [diakses pada 7 September 2019].

Anonim. $2015^{b}$. Pengertian definisi kangkung dan morfologi. http://duniaplant[diakses pada 19 Agustus 2019].

Anonim. 2018. Alat Praktis Untuk Tanam Benih Langsung (TABELA). https://tanikita.com/tabela cerdas alat praktisuntuk tanam benih langsung tabelapadi [diakses pada 05 Agustus 2019].

Agustin, D., dan Indira Rezkisari. 2019. Manfaat Kangkung Untuk Kesehatan. https://gaya hidup.republika.co.id/berita/gaya hidup/infosehat/19/01/07/pkxxxe328-5-manfaat kangkung untuk kesehatan [diakses pada 19 Agustus 2019].

Handoyo, Halim. 2013. Toko Gerobak. http://tokogerobak.blogspot.com/2013/06/jual gerobak alumunium siap pakai.html?m=1 [diakses pada 8 September 2019].

Haryanto. 2009. Bertanam Kangkung Raksasa di Pekarangan. Kanisius, Yogyakarta. Hal 136.

Juan. 2018. Fungsi dan Bagian Bagian Roda. https://www.teknik-otomotif.com/2018/04/fungsi dan bagian bagian roda kendaraan.html [diakses pada 7 September 2019].

Rachmawati, A. 2013. Pengenalan Alat Penanaman. Laporan Praktikum Mekanisasi Pertanian. Laboratorium Hama Dan Penyakit Tanaman. Jurusan Agroekoteknologi Fakultas Pertanian. Universitas Lampung, Lampung.

Rukmana, R. 1994. Bertanam kangkung. Kanisius, Yogyakarta. Hal 1-44. 
Salimin. 2012. Perancang Alat Tabur Benih Padi Langsung. Ilmiah teknik mesin. Hal 245250 .

Sulaiman, A. 2017. Kandungan Manfaat dari Sayur Kangkung Bagi Kesehatan. https://nusantaranews.co/kandungan dan manfaat kangkung bagi kesehatan/[diakses pada 8 September 2019].

Syafri, E. 2010. Desain Mesin Penanam Jagung Terintegrasi Dengan Penggerak Traktor Roda Dua. Program Pascasarjana. Institu 